\title{
Konsep Bermegah (Boasting) dalam Surat Roma dan Implikasinya Bagi Gereja Masa Kini
}

\author{
Shintia Maria Kapojos, Hengki Wijaya 1)* \\ 1) Sekolah Tinggi Filsafat Jaffray Makassar \\ *)Penulis korespondensi: oshinmaria@gmail.com
}

Received: 15 Feb. 2019 / Revised: 14 April 2019 / Accepted: 07 May 2019

\section{Abstrak}

Tujuan penulisan ini untuk menjelaskan konsep bermegah dalam kitab Roma dan implikasinya bagi gereja masa kini. Dalam konsep 'bermegah', Paulus hendak mengaitkannya dengan dasar menaruh tempat kepercayaan yang benar. Paulus menolak semua dasar bermegah di luar dari Injil. Hanya Injil yang dapat membuktikan bahwa semua kemegahan yang lainnya tidak dapat diandalkan. Kehidupan orang percaya akan bermegah bukan hanya di dalam hal-hal yang baik saja, namun hingga ke tahap menderita, orang percaya akan tetap bermegah. Kesengsaraan di dalam kehidupan orang percaya bukan lagi menjadi tanda murka Allah melainkan bagaimana mereka telah memperolah keselamatan dari murka itu. Orang percaya dalam komunitas gereja diajarkan untuk bermegah pada halhal yang memuliakan Tuhan, dan tidak bermegah atas keberhasilan pelayanan dan hal-hal yang duniawi.

Kata-kata kunci: Bermegah, Kitab Roma, Gereja, kemuliaan

\section{Abstract}

The purpose of this paper is to explain the concept of boasting in the book of Romans and its implications for the church today. In the concept of 'boasting', Paul wants to relate it to the basis of placing a place of true trust. Paul rejects all the bases boasting outside of the gospel. Only the gospel can prove that all the other splendors are unreliable. The lives of believers will boast not only in good things, but to the stage of suffering, 
believers will still boast. The misery in the lives of believers is no longer a sign of God's wrath but how they have obtained the salvation from that wrath. Believers in the church community are taught to boast about things that glorify God, and not boast of the success of ministry and worldly things. Keywords: boasting, Romans letter, church, glory

\section{Pendahuluan}

Apakah manusia dapat bermegah dengan apa yang dilakukannya untuk dunia ini? Segala yang telah manusia lakukan untuk kemajuan dunia ini yang begitu pesat, namun semuanya itu tidak dapat dibandingkan dengan apa yang telah dilakukan oleh Yesus yang telah menebus dosa-dosa manusia. Gereja-Nya tidak dapat bermegah karena banyaknya jiwa-jiwa bertobat, atau karena hamba-hamba-Nya luar biasa dalam menjalankan misi-Nya. Sekali-kali itu semuanya terjadi oleh karena Yesus.

Istilah bermegah dan kata-kata yang serumpun merupakan salah satu istilah kunci dalam surat-surat Paulus. ${ }^{1}$ Hal ini nampak jelas dalam beberapa kitab yang dituliskan oleh rasul Paulus. Dalam suratnya kepada jemaat di Filipi, ia menggunakan istilah ini, ketika ia berkata, "karena kita orang-orang bersunat, yang beribadah oleh Roh Allah, dan bermegah dalam Kristus Yesus dan tidak menaruh percaya pada hal-hal lahiriah" (Filipi 3:3). Kata yang sama juga digunakan dalam Galatia 6:14, "Tetapi aku sekali-kali tidak mau bermegah, selain dalam salib Tuhan kita Yesus Kristus, sebab olehnya dunia telah disalibkan bagiku dan aku bagi dunia." Selain kitab Filipi dan Galatia, Paulus juga menggunakan istilah yang sama ketika menuliskan suratnya kepada jemaat di Korintus yang tercatat dalam 1 Korintus 1:29, "supaya tidak ada seorang manusia pun yang memegahkan diri di hadapan Allah."

Istilah 'bermegah' berasal dari bahasa Yunani $\kappa \alpha u \chi \alpha ́ o \mu \alpha \iota$ (kaukhaomai) yang secara harafiah dapat diartikan kebanggaan dan kemuliaan. $^{2}$ Dalam terjemahan LAI, kaukhaomai diterjemahkan dengan kata 'bermegah' yang juga memiliki arti yang sinonim dengan arti kebanggaan. Dalam tulisan Paulus kepada jemaat di Roma, istilah ini

\footnotetext{
${ }^{1}$ Th. van den End, Surat Roma (Jakarta: BPK Gunung Mulia, 1995), 110.

2"Strong's Concordance," https://biblehub.com/greek/2744.htm, s.v. kauchaomai: to boast.
} 
seringkali dikaitkan dengan pembahasan mengenai hukum taurat dan iman. Penggunaannya dalam bentuk kata kerja menggunakan kata kaukhastai yang merupakan istilah favorit yang digunakan rasul Paulus, yang muncul sebanyak tiga puluh kali. ${ }^{3}$ Beberapa kali istilah ini muncul dalam kitab Roma yaitu, pada pasal 2:17-29, 3:21-31, 4:1-25, 5:1-11, dan 15:14-21. Jika dihitung, istilah 'bermegah' muncul sebanyak delapan kali dalam kitab Roma $(2: 17,23 ; 3: 27 ; 4: 2 ; 5: 2,3,11 ; 15: 17) .{ }^{4}$ Dalam penggunaannya di kitab Roma, istilah bermegah digunakan dalam bentuk bervariasi, entah dalam bentuk kata kerja maupun kata benda. Namun kebanyakan ditemui dalam penggunaanya adalah dalam bentuk kata kerja yang digunakan sebanyak lima kali $(2: 17,23 ; 5: 2,3,11)$ dan tiga kalinya dalam bentuk kata benda $(3: 27$; 4;2: 5:17).

Bermegah dalam surat Roma menurut Luther difokuskan kepada aktivitas bermegah, dan sikap yang sia-sia. Sementara komentar Calvin berfokus pada formulasi teologis, dan definisi bermegah sebagai kelayakan yang sepadan atau sesuai. ${ }^{5}$ Melalui tulisan ini, penulis menjelaskan konsep bermegah yang dimaksudkan oleh Paulus dalam surat Roma, dan implikasinya dalam gereja masa kini.

\section{Metode Penelitian}

Metode penelitian yang digunakan adalah penelitian kualitatif hermeneutika yaitu kajian biblika yang menjelaskan konsep berdasarkan nas Alkitab, melakukan ekposisi berdasarkan nas, dan menguraikan impikasi praktis nas tersebut dalam kehidupan orang percaya, gereja, dan masyarakat. ${ }^{6}$ Melalui langkah-langkah tersebut maka penulis mendapatkan kebaruan yang akan memberikan wawasan baru bagi pendidikan teologi.

\footnotetext{
${ }^{3}$ Matthew Black, The New Century Bible Commentary (Grand Rapids: Eerdmans Publishing Company, 1989), 20.

${ }^{4}$ Dalam terjemahan LAI, istilah 'bermegah' muncul 10 kali, namun jika dilihat dari bahasa aslinya, istilah ini hanya muncul 8 kali.

${ }^{5}$ Simon J. Gathercole, Where Is Boasting? Early Jewish Soteriology and Paul's Response in Romans 1-5 (Grand Rapids, Mich: William B. Eerdmans Pub. Co, 2002), 2.

${ }^{6}$ Hengki Wijaya, Metodologi Penelitian Pendidikan Teologi (Makassar: Sekolah Tinggi Theologia Jaffray, 2016), 39-41.
} 


\section{Pembahasan}

\section{Taurat: Kebanggaan Orang Yahudi (Roma 2:17-23)}

Istilah "kemegahan" dan "bermegah", Paulus beberapa kali memakai istilah ini untuk menggambarkan keyakinan bangsa Yahudi akan hak istimewa mereka sebagai umat Allah. ${ }^{7}$ "Nama 'Yahudi' itu mula-mula menjadi sebutan anggota suku Yehuda saja, tetapi mulai berganti 'Israel' sejak zaman pembuangan ke Babel. Namun nama 'Israel” tetap menjadi sebuah khidmat. Meskipun banyak dipakai orang diluar dengan nada penghinaan, disini dalam Roma 2:17, Yahudi merupakan nama kehormatan."8 Selain sebutan Yahudi dikenal sebagai nama kehormatan. Orang Yahudi selalu identik dengan kaitannya mengenai 'hukum taurat', karena status mereka sebagai umat pilihan Allah, melalui hak inilah mereka dapat mengenal hukum taurat.

Dalam pasal 2 sangat jelas terlihat, bagaimana Paulus menunjukkan eratnya hubungan keyahudian dengan hukum Taurat. Hal ini nampak jelas dengan munculnya beberapa kali kata hukum taurat dalam pasal 2. Kata hukum taurat setidaknya diulangi sebanyak sepuluh kali oleh Paulus dalam pasal ini. Hal ini menegaskan betapa pentingya hukum taurat di dalam kehidupan orang Yahudi. Menurut Craig, "Pelajaran taurat adalah pusat untuk orang farisi dan agaknya untuk kesalehan pengajar-pengajar Yahudi lainnya." 9

Dalam Roma pasal 2, Paulus menunjukkan peranan taurat dalam kaitannya dengan orang Yahudi, yang menjadi alasan orang Yahudi bermegah di dalamnya, yaitu hukum taurat dijadikan sebagai sandaran (2:17), melalui hukum taurat orang Yahudi dapat tahu akan kehendak-Nya (2:18), dapat mengetahui mana yang baik dan yang tidak (2:18), dapat menuntun orang yang buta (2:19), menjadi pendidik bagi orang bodoh, pengajar bagi orang yang belum dewasa dan melalui taurat memiliki kegenapan segala kepandaian dan kebenaran (2:20). Menurut Dave Hagelberg, "Daftar kemegahan atau kebanggaan orang Yahudi itu mirip dengan apa yang dikatakan Paulus mengenai dirinya sendiri sebelum ia

7 Herman Ridderbos, Paulus Pemikiran Utama Theologinya (Surabaya: Momentum, 2010), 140.

${ }^{8}$ Th. van den End, Surat Roma (Jakarta: BPK Gunung Mulia, 1995), 110.

${ }^{9}$ Craig S. Keener, Romans (Unites States America: Cascade Books, 2009), 46. 
mengenal Kristus (Flp. 3:3-7)". ${ }^{10}$ Hal ini jelas karena, "Rasul Paulus adalah seorang yang dilahirkankan sebagai seorang Yahudi, dan ia sangat bangga akan hal tersebut sebelum ia mengenal Yesus". ${ }^{11}$

Dari uraian dalam pasal 2 ini, menurut Hodges, "kebanggaan mereka terdiri atas dua bagian. Bagian pertama, dalam pasal 2:17, menceritakan hak istimewa yang dimiliki sebagai umat pilihan Allah. Bagian kedua menceritakan pengertian khusus yang dimiliki mereka." ${ }^{12}$ Namun hak istimewa itu ditolaknya. Keberadaan mereka sebagai umat pilihan ditolak dalam Kerajaan Allah akibat ketidakpercayaan mereka terhadap Kristus. Orang Israel salah mengerti bukan hanya terhadap tujuan Mesias, namun syarat dasar dari perjanjian Allah. Kristus bagi orang Yahudi menjadi suatu sandungan, namun bagi orang percaya, Ia menjadi batu fondasi. ${ }^{13}$ Dengan demikian orang Yahudi yang menolak Kristus bermegah karena hak istimewa sebagi umat pilihan Allah.

Mengenai penjelasan kemegahan ini, Rasul Paulus menggunakan kata kaukhaomai yang secara khusus jelas menyolok dalam kritiknya kepada orang Yahudi. ${ }^{14}$ Meskipun mengandung pernyataan positif, namun di tengah penjelasan segala kemegahan tersebut pada bagian ini, "Paulus menggunakan sebuah gaya retorika yang hidup yang disebut kecamankecaman, biasanya digunakan untuk mengajar." 15 Meskipun demikian, Paulus tidak menyangkali tentang kebenaran tersebut, bahwa memang melalui taurat mereka dapat mengetahui tentang kehendak Allah, dapat menuntun orang dalam kebenaran dan bahkan memiliki kegenapan segala kepandaian dan kebenaran. Akan semua hal tersebut, orang-orang Yahudi memang dapat bermegah. Namun menurut Paulus ada hal yang perlu dipahami oleh orang Yahudi secara lebih dalam dari segala kemegahan yang dapat mereka tonjolkan. 2013), 60 .

${ }^{10}$ Dave Hagelberg, Tafsiran Roma dari Bahasa Yunani (Bandung: Kalam Hidup,

${ }^{11}$ R. E. Harlow, Alive and Free (Canada: Everyday Publication, 1977), 26.

${ }^{12}$ Hodges dalam Dave Hagelberg, Tafsiran Roma dari Bahasa Yunani (Bandung: Kalam Hidup, 2013), 60.

${ }^{13}$ Julian Frank Rouw, "Kajian Konseptual Tentang Pemilihan Allah Dalam Roma 9," Evangelikal: Jurnal Teologi Injili dan Pembinaan Warga Jemaat 1, no. 2 (2017): 183.

${ }_{14}$ Douglas Moo, The Wycliffe Exegetical Commentary Romans 1-8 (Chicago: Moody Press, 1991), 156.

${ }^{15}$ Craig S. Keener, Romans (Unites States America: Cascade Books, 2009), 42. 
Paulus mempertanyakan tentang segala kemegahan yang dibanggakan orang Yahudi dengan mengemukakan pertanyaan-pertanyaan. Menurut Cranfield, pasal 2:21-22 terdiri atas empat pertanyaan retoris. ${ }^{16}$ Namun dalam bukunya yang berjudul Tafsiran Rasul Paulus kepada Orang Rum, R. A. Jaffray mengemukakan lima pertanyaan Paulus dari Roma 2:2123 sebagai berikut: ${ }^{17}$

1. Engkau mengajar orang lain, tidak perlu engkau mengajar dirimu sendiri (ayat 21);

2. Engkau yang mengajar bahwa jangan orang mencuri, tidakkah engkau pula mencuri (ayat 21);

3. Engkau yang mengatakan orang jangan berzinah, tidakkah engakau berzinah (ayat 22);

4. Engkau yang membenci segala berhala, tidakkah engkau merampas rumah berhala (ayat 23);

5. Engkau yang memegakan dirimu di dalam taurat, tidakkah engkau menghina Allah dengan melanggar hukum taurat? (ayat 23).

Orang Yahudi dapat bermegah di dalam taurat yang telah diberikan Allah kepada mereka sebagai umat pilihan-Nya. Namun meskipun demikian sangatlah ironi ketika segala kemegahan tersebut akhirnya berujung kepada kesombongan. Apalagi "ketika orang tersebut merasa bahwa ia tidak harus merepotkan diri dengan hal ketaatan dan boleh menghakimi orang lain. Di situ ia sudah bersalah". ${ }^{18}$

Melalui pertanyaan-pertanyaan yang diajukan Paulus ini, dengan terang-terangan ia menunjukkan kekontrasan kehidupan orang Yahudi dengan kemegahan mereka di dalam taurat. Menurut orang Yahudi, taurat adalah sarana untuk bisa dibenarkan oleh perbuatan dan senjata untuk melawan kuasa dosa. ${ }^{19}$ Namun dengan tegas Paulus mengkritik perbuatanperbuatan mereka yang berlindung dibalik taurat untuk melakukan segala yang tidak sesuai dengan taurat itu sendiri. Pada intinya, Paulus memakai 2013), 61 .

${ }^{16}$ Dave Hagelberg, Tafsiran Roma dari Bahasa Yunani (Bandung: Kalam Hidup,

${ }^{17}$ R. A. Jaffray, Tafsiran Surat Rasul Paulus kepada Orang Rum (Bandung: Kalam Hidup, 1968), 31. 2013), 63 .

${ }^{18}$ Dave Hagelberg, Tafsiran Roma dari Bahasa Yunani (Bandung: Kalam Hidup,

19 Herman Ridderbos, Paulus Pemikiran Utama Theologinya (Surabaya: Momentum, 2010), 134. 
dua cara untuk membuktikan ketidakcukupan Taurat sebagai sarana keselamatan, untuk membantah dua fungsi penebusan orang Yahudi kenakan atas taurat. ${ }^{20}$ Dengan demikian menunjukkan bahwa taurat yang dianggap sebagai kemegahan bagi kehidupan Yahudi tidak sanggup untuk dijadikan patokan dasar bermegah bagi keselamatan umat Allah.

\section{Dasar Bermegah: Iman dan Bukan Perbuatan (3:27; 4:2)}

Pada umumnya orang Yahudi bermegah atas taurat, karena paling tidak mereka memiliki hukum taurat yang diberikan Allah kepada mereka sebagai umat pilihan-Nya. Mereka bermegah karena dengan demikian mereka diberi kemungkinan untuk melalui perbuatannya menjadi 'benar' di hadapan Allah. ${ }^{21}$ Orang Yahudi tidak menyadari bahwa malahan dengan hukum taurat tersebut justru mendatangkan hukuman atas mereka yang berupaya melakukannya (3:20).

"Secara praktis, bermegah, dan bersandar di dalam taurat berarti bermegah di dalam ketaatan kepada taurat (Ef. 2:9). Itu berarti menaruh kepercayaan kepada pekerjaan manusia, kepada daging (Flp. 3:3) dan mendirikan 'kebenaran mereka sendiri (Rm. 10:3)". ${ }^{22}$ Hal ini telah membuat orang Yahudi bergeser dari titik awal mereka di panggil sebagai umat-Nya, yang mana pemilihan Allah atas mereka hanya berdasarkan kepada anugerah Allah saja. Dengan ini, Israel tidak lagi bersandar pada anugerah Allah dan pemilihan kovenan-Nya, tetapi pada aktivitas manusia, sehingga mereka menaruh pengharapan dan kepercayaan di atasnya. ${ }^{23}$

Sebenarnya Paulus tidak menentang tentang taurat, tetapi yang menjadi pertentangan yang ditekankan Paulus mengenai pengandalan terhadap taurat untuk dijadikan dasar pembenaran untuk segala perbuatan mereka. Oleh karena itu, dalam pasal 3:27 Paulus mengemukakan sebuah pertanyaan retoris, dan langsung menjawabnya dengan menentang apa yang dibanggakan orang Yahudi di dalam taurat. Paulus dengan tegas mengemukakan tidak ada alasan bagi seseorang untuk bermegah di dalam taurat, dengan menganggap bahwa dengan melakukan hukum taurat tersebut

${ }^{20}$ Herman Ridderbos, Paulus Pemikiran Utama Theologinya, 134.

${ }^{21}$ Th. van den End, Surat Roma (Jakarta: BPK Gunung Mulia, 1995), 110.

22 Herman Ridderbos, Paulus Pemikiran Utama Theologinya (Surabaya: Momentum, 2010), 140.

${ }^{23}$ Ibid., 140. 
seseorang akan dibenarkan (3:28). Paulus menjelaskan kebenaran Allah kepada mereka yang mana melalui kebenaran ini tidak ada lagi tempat lainya yang dapat dijadikan kebanggaan bagi orang Yahudi untuk bermegah, selain kebenaran Allah melalui iman kepada Yesus.

Hanya Injil yang dengan jelas menunjukkan bahwa tidak ada tempat bagi kemegahan. Di dalam Injil, "hukum perbuatan" digantikan oleh "hukum iman" yang diatur oleh tatanan yang lain. (Rm.4:2). ${ }^{24}$ Disini Paulus menunjukkan dasar bermegah yang sebenarnya kepada orang Yahudi bahwa alasan untuk bermegah hanya melalui iman saja. Oleh karena itu, "semua kesombongan atas usaha manusia tidak ada lagi." 25 Segala kemegahan yang dibanggakan tidak berarti lagi jika dibandingkan dengan kebenaran yang ditunjukkan Allah bagi umat-Nya.

Seperti yang ditunjukkan oleh kehidupan Abraham. Abraham adalah orang yang sangat dikenal dikalangan orang Yahudi, sebab sebelum ada taurat dia sudah melakukan taurat. Ia dijadikan tokoh teladan yang penting dalam sejarah umat Israel. Meskipun ia adalah seorang yang taat kepada Allah, Paulus menekankan bahwa ketaatannya itu tidak menjadi dasar untuk bermegah di hadapan Allah. Menurut Paulus, iman Abraham itulah yang menyebabkan Allah memperhitungkan dia sebagai orang yang benar. ${ }^{26}$ Kemegahan Abraham bukanlah terletak kepada perbuatannya, tetapi kepada imannya kepada Allah. Bagi Abraham, dibenarkan Allah adalah anugerah, bukan jerih payah (4:5). ${ }^{27}$

Jika Abraham dibenarkan hanya melalui iman, maka hal ini pun seharusnya diikuti oleh keturunan Abraham. Disini Paulus memberikan contoh yang sangat jelas bagi orang Yahudi bahwa mereka pun harus mengikuti teladan Abraham yang hanya dibenarkan melalui iman.

Iman kepada Yesus, manusia dapat dibenarkan. Inilah berita yang disampaikan Paulus secara tegas bagi umat-Nya. Yesus Kristus telah ditentukan Allah menjadi jalan pendamaian karena iman, dalam darah-Nya

${ }^{24}$ Ibid., 141.

${ }^{25}$ William Barclay, Pemahaman Alkitab Setiap Hari Roma (Jakarta: BPK Gunung Mulia, 1986), 95.

${ }^{26}$ William Barclay, Pemahaman Alkitab Setiap Hari Roma, 99.

${ }^{27}$ Paul Cheung, Materi Kelas Surat Roma (Makassar: Sekolah Tinggi Theologia Jaffray, 2016), 14. Tidak dipublikasikan. 
Konsep Bermegah (Boasting) dalam....(Shintia Maria, Hengki Wijaya)

(Rm.3:25). Melalui penebusan-Nya setiap orang dapat dibenarkan. Penebusan yang dilakukan-Nya pun bukan berdasarkan perbuatan manusia melainkan berdasarkan kasih-Nya (Rm. 3:24). Oleh karena itu, sudah sepatutnya setiap orang hanya beriman kepada Yesus saja, beriman kepada Yesus berarti menjadikan Dia sebagai Tuhan, mempercayai Dia, bersandar pada-Nya, setia dan tulus kepada-Nya, inilah arti percaya yang ditekankan dalam kitab Roma. ${ }^{28}$ Dari kebenaran inilah kita dapat bermegah di dalamnya.

\section{Jalan Iman: Bermegah dalam Pengharapan, Kesengsaraan, dan Allah (Roma 5:1-11)}

"Dalam pasal 1:18-4:25 Paulus telah mengatakan bagaimana orang dibenarkan di hadapan Allah, yaitu oleh iman. "Kata-kata pertama dari ayat pertama pasal 5, 'kita yang dibenarkan karena iman, seakan-akan menyimpulkan seluruh uraian yang panjang itu. 'Dibenarkan' mengandung arti bahwa kini hubungan kita dengan Allah sudah dipulihkan."29 Melalui pembenaran karena iman, sekarang Paulus mendaftarkan berkat-berkat yang diperoleh bagi mereka yang dibenarkan. ${ }^{30}$ Dalam pasal 5 surat Roma, iman diperlukan untuk menerima kasih karunia Allah (Rm. 5:2; 5:20-21). ${ }^{31}$ Oleh kasih karunia Allah, orang percaya dibenarkan oleh imannya kepada Yesus Kristus.

Salah satunya yaitu damai sejahtera dengan Allah (5:1). Pembenaran dan pendamaian adalah dua istilah yang penting dalam menjelaskan tentang karya Allah bagi manusia. Dave Hagelberg menjelaskan hubungan pembenaran dan pendamaian dengan mengutip pernyataan Cranfield, "Allah karena Dia adalah Allah, selalu memberikan damai kepada orang yang dibenarkan-Nya." ${ }^{32}$ Dengan pernyataan ini dapat dikatakan bahwa kasih Allahlah dasar pembenaran dan pendamaian manusia. Manusia yang dulunya bermusuhan dengan Allah, kini dapat didamaikan

${ }^{28}$ Ibid., 14.

${ }^{29}$ Th. van den End, Surat Roma (Jakarta: BPK Gunung Mulia, 1995), 216.

${ }^{30}$ F. F. Bruce, Romans (Grand Rapids: InterVarsity Press, 1985), 114.

${ }^{31}$ Hanny Frederik, "Konsep Persatuan Dengan Kematian Dan Kebangkitan Kristus Berdasarkan Roma 6:1-14," Jurnal Jaffray 13, no. 2 (September 29, 2015): 238. 2013), 104.

${ }^{32}$ Dave Hagelberg, Tafsiran Roma dari Bahasa Yunani (Bandung: Kalam Hidup, 
dengan-Nya (5:1). Perdamaian dapat dicapai melalui Yesus, karena kematian dan kebangkitan-Nya. ${ }^{33}$ Tanpa kehadiran Yesus manusia tidak dapat menghampiri Allah. Melalui pendamaian ini, tidak ada lagi hukuman bagi manusia, malahan sukacita yang datangnya dari Allah. Menurut F. F. Bruce, "kedamaian dan sukacita adalah berkat kembar dari Injil. Di dalam sukacita, terdapat tiga objek yang disebutkan, yaitu bermegah dalam harapan kemuliaan, bermegah dalam penderitaan dan bermegah dalam Allah."34 Berikut ini akan membahas ketiga objek ini.

\section{Bermegah dalam Pengharapan Kemuliaan Allah (5:2)}

Setelah berbicara mengenai pendamaian, menarik untuk dilihat bahwa Paulus kembali mengungkapkan istilah bermegah. Menurut Th. van den End,

Dalam Perjanjian Lama, 'bermegah' dipakai dalam arti negatif maupun positif. Terdapat contoh yang jelas dalam Yeremia 9:23. Orang dapat bermegah karena kebijaksanaannya, kekuatannya, kekayaannya. Artinya tentu: membanggakan hal-hal tersebut, bergembira karenanya. Tetapi di dalamnya termasuk unsur: mengandalkan hal-hal itu. Akhirnya ada juga unsur: memuji-muji, menyembah. Dalam Yeremia 9:23, 'bermegah' itu ditolak kalau mengenai hal-hal milik manusia sendiri, hasil prestasi manusia sendiri. Sebaliknya manusia diajak bermegah karena 'mengenal' Allah, artinya karena hidup dalam persekutuan dengan Allah. ${ }^{35}$

Dalam pasal 2:17, sebelumnya Paulus telah mengkritik orang Yahudi yang membanggakan diri dengan taurat yang dimilikinya. Namun kali ini istilah bermegah bukan berisikan tentang kecaman atau kritikan melainkan sukacita karena pembenaran yang dilakukan Allah, sehingga manusia dapat hidup dalam persekutuan dengan Allah.

Frasa bermegah dalam pengharapan akan menerima kemuliaan Allah merupakan sebuah bagian yang akan diterima orang percaya yang telah masuk dalam anugerah Allah (2:2a). Bagi mereka yang belum masuk dalam persekutuan dengan Allah, hal ini tidak dapat menjadi bagiannya. Disini,

\footnotetext{
${ }^{33}$ Dave Hagelberg, Tafsiran Roma dari Bahasa Yunani, 70.

${ }^{34}$ F. F. Bruce, Romans (Grand Rapids: InterVarsity, 1985), 114-115.

${ }^{35}$ Th. van den End, Surat Roma (Jakarta: BPK Gunung Mulia, 1995), 220.
} 
Paulus menggabungkan dua istilah yang penting dalam frasa ini, yaitu 'pengharapan' dan 'kemuliaan'. Kedua istilah ini memiliki makna yang akan datang yang masih belum terjadi. Berkaitan dengan istilah pengharapan, Dave Hagelberg mengatakan bahwa 'Kata 'pengharapan' adalah sebuah istilah yang berarti antisipasi yang penuh keyakinan dari apa yang belum kita lihat". ${ }^{36}$ Dengan frasa ini, Paulus menunjukkan hal yang lebih jauh dari apa yang bisa dipandang oleh manusia secara kasat mata, yaitu pengharapan tentang kemuliaan Allah. Untuk menjelaskan kemuliaan Allah, Th. van den End mengungkapkan,

Kata-kata ini dapat diartikan dengan dua cara. Pertama, 'kemuliaan Allah' adalah kemuliaan Allah sendiri, yang akan dinyatakan dengan sepenuhnya pada akhir zaman. Kemuliaan Allah itu adalah cahayaNya, keelokan-Nya, kehormatan-Nya, kekuasaan-Nya. Tetapi 'kemuliaan Allah' adalah juga kemuliaan yang diberikan kepada manusia ciptaan-Nya, dan yang seakan-akan merupakan pancaran kemuliaan-Nya sendiri. Kemuliaan dengan arti kedua itulah yang dimaksud disini, manusia kehilangan sebagian terbesar kemuliaan itu akibat dosa, meskipun masih ada yang tinggal, bandingkan dengan Mazmur 8. Akan tetapi pada zaman akhir, yang merupakan pula saat kebangkitan orang mati, kemuliaan itu akan dipulihkan (Rm. 8:18, 21; 1 Kor. 15:43).

Kemuliaan yang akan diterima orang percaya sungguh luar biasa, kemuliaan ini tidak diperoleh melalui usaha manusia melainkan hanya dapat dicapai dengan penebusan Yesus. Selama manusia tetap tinggal dalam tubuh yang fana ini, pengharapan tetap ada. ${ }^{37}$ Pengharapan dalam Allah bukanlah sebuah janji-janji yang tidak pasti, malah sebaliknya, 'menantikan hal-hal yang sudah diyakini' ${ }^{38}$ pasti terjadi. Satu yang pasti dipenuhi, bagi yang menghargainya adalah telah disiapkan garansi dari realisasinya dalam pemberian Roh Kudus, yang memenuhi hati mereka dengan cinta dari Tuhan. ${ }^{39}$ 2013), 106.

${ }^{36}$ Dave Hagelberg, Tafsiran Roma dari Bahasa Yunani (Bandung: Kalam Hidup,

${ }^{37}$ F. F. Bruce, Romans (Grand Rapids: InterVarsity, 1985), 114.

${ }^{38}$ William Barclay, Pemahaman Alkitab Setiap Hari Roma, (Jakarta: BPK Gunung Mulia, 1986), 220.

${ }^{39}$ F. F. Bruce, Romans (Grand Rapids: InterVarsity, 1985), 114. 
Melalui semua pemberian Allah inilah (pembenaran-Nya), Paulus menyatakan kepada jemaat di Roma untuk bermegah. Karena pembenaran ini merupakan anugerah Allah bagi setiap mereka yang dibenarkan. Oleh karena itu, umat-Nya patut bermegah, karena Allah telah menyiapkan berkat-berkat bagi orang percaya yang ada di dalam Tuhan. Ini merupakan berita sukacita, di masa yang akan datang telah tersedia jaminan yang indah bagi setiap orang yang percaya dan yang berharap kepada-Nya.

\section{Bermegah dalam Kesengsaraan (5:3)}

Jikalau sebelumnya Paulus mengatakan kepada jemaat di Roma untuk bermegah karena pengharapan akan menerima kemuliaan Allah. Dalam ayat selanjutnya Paulus melanjutkan berita sukacita dengan menyatakan bahwa umat dapat bermegah dalam kesengsaraan. Menurut Douglas Moo, "Disini dengan cepat, Paulus berputar dari bermegah dalam pengharapan kemuliaan Allah kepada bermegah dalam kesengsaraan". ${ }^{40}$ Ini merupakan pernyataan yang menarik yang diungkapkan rasul Paulus kepada jemaat di Roma, yang juga sekaligus dapat mengundang kritik tentang pengajarannya, sebab diawal pasal 5 ini, Paulus telah mengungkapkan tentang kedamaian dengan Tuhan bagi mereka yang telah dibenarkan, namun disaat yang sama pula Paulus menyatakan bahwa seorang yang percaya mengalami kesakitan, penganiayaan, kesulitan, dan sejenisnya. ${ }^{41}$ Sepertinya pernyataan Paulus ini akan sulit diterima bagi banyak orang.

Paulus menyatakan kepada jemaat untuk bermegah, tapi anehnya bermegah di dalam kesengsaraan. Sungguh, orang Kristen yang dulu dan sekarang, pasti tercegang tentang realita berkat dalam wajah penderitaan. ${ }^{42}$ Sebab biasanya seseorang akan bermegah ketika ia memiliki hal-hal yang patut dibanggakan, seperti yang terdapat dalam ayat 2:17, di mana orang Yahudi berbangga dengan taurat mereka. Pada dasar orang akan bermegah dengan sesuatu yang dinilai baik untuk dibanggakan, entah kekayaannya, kehormatannya, kepintarannya dan sebagainya, Namun dalam ayat ini, Paulus mengatakan untuk 'bermegah dalam kesengsaraan'. Allah melalui Roh-Nya bergabung di dalam ratapan penderitaan manusia sebagai ciptaan,

${ }^{40}$ Douglas Moo, The Wycliffe Exegetical Commentary Romans 1-8, (Chicago: Moody Press, 1991), 309.

${ }^{41}$ Ibid, 310.

42 Ibid., 310. 
sehingga Roh itu berdoa untuk kita kepada Allah dengan keluhan-keluhan yang tidak terucapkan (Rm. 8:26). Ini adalah salah satu ungkapan solidaritas yang dimaksud. Allah tidak membiarkan manusia menderita sendirian. ${ }^{43}$ Bermegah dalam penderitaan berarti Allah hadir untuk memberikan kekuatan di dalam penderitaan orang percaya.

Kesengsaraan adalah sesuatu yang dianggap tidak menyenangkan bagi banyak orang pada umumnya, karena tidak seorang pun ingin untuk mengalami peristiwa yang sengsara, Namun dalam 5:3, kata bermegah menunjukkan kepada hal yang positif, dan bukan negatif. Dengan demikian, kesengsaraan yang dimaksudkan oleh Paulus dalam ayat ini, patut diperhatikan. Di sini Paulus hendak menunjukkan apa yang patut dibanggakan dari kesengsaraan yang menjadi bagian orang percaya.

Kata yang dipakai untuk kesengsaraan ialah, thlipis, yang secara harafiah, artinya tekanan. ${ }^{44}$ Menurut Douglas Moo, kata thlipis adalah kata yang langsung berkaitan dengan pernyataan iman orang percaya kepada Tuhan. ${ }^{45}$ Selanjutnya, Th. van den End memberikan latar belakang dari Perjanjian Lama untuk memahami kata kesengsaraan yang merupakan kata yang pokok dari Roma 5:3 sebagai berikut:

Kita banyak menemukannya dalam Kitab Mazmur dan dalam kitabkitab PL yang lain. Misalnya: penindasan oleh musuh (mis. Hak. 10:8), kesesakan karena tersesat dalam padang gurun (Mzm. 107:19). Yang berada dalam sengsara adalah bangsa Israel. Dalam PL kesengsaraan itu merupakan hukuman Tuhan atas ketidaksetiaan, tetapi juga cara Tuhan menyiapkan bagi diri-Nya suatu bangsa yang taat. Kesengsaraan itu akan memuncak pada zaman akhir (Dan. 12;1; Zef. 1:15). Dalam Kitab Mazmur kesengsaraan orang saleh yang tampil ke depan. Sengsara itu adalah sesuatu yang wajar. "kemalangan orang benar yang banyak" (Mzm. 34:20). Orang benar itu 'berjalan dalam kesesakan' (138:7). Sengsara itu pun datangnya

${ }^{43}$ Sonny Zaluchu, "Penderitaan Kristus Sebagai Wujud Solidaritas Allah Kepada Manusia," DUNAMIS: Jurnal Teologi dan Pendidikan Kristiani 2, no. 1 (November 4, 2017): 71.

44 William Barclay, Pemahaman Alkitab Setiap Hari Roma (Jakarta: Gunung Mulia, 1986), 95.

45 Douglas Moo, The Wycliffe Exegetical Commentary Romans 1-8 (Chicago: Moody Press, 1991), 309. 
dari Tuhan (Mzm. 66:11; 71:20), tetapi Tuhan pula yang menyelamatkan orang benar dari padanya.

Dalam sastra Yahudi pada zaman antar perjanjian, makna kesengsaraan ialah: hukuman atas pelanggaran, dorongan agar bertobat, penambahan jasa amal, bahkan tebusan dosa. Tetapi yang penting dalam memahami makna ayat-ayat ini ialah pertanyaan yang oleh orang-orang Yahudi termasuk sementara orang Yahudi Kristen, diarahkan kepada Paulus (dan kepada gereja Kristen masa kini): kalau memang benar bahwa Sang Mesias sudah datang dan bahwa Dia telah memulihkan hubungan antara orang-orang percaya dengan Allah (pembenaran), bagaimana dapat dijelaskan bahwa orang-orang percaya masih tetap mengalami penderitaan? Terhadap pertanyaan kritis ini Paulus harus menerangkan pandangan Kristen tentang penderitaan. ${ }^{46}$

Memang jelas bahwa kesengsaraan tidak terlepas dari kehidupan orang percaya. Tapi perlu diingat bahwa jikalau penderitaan itu disebabkan oleh pelanggaran, maka hal tersebut tidak dapat ditolerir. Seperti yang diungkapkan oleh Douglas Moo, "bahwa yang serupa dengan pelanggaran tidak dapat dibenarkan." 47 Orang percaya menderita sengsara kalau dan karena kita hidup dalam persekutuan dengan Kristus (Kol. 1:24; Flp. 3:10; band 2 Kor. 1:5). Atau dengan perkataan lain: sebagaimana Kristus 'harus' menderita sengsara, begitu pula orang Kristen 'harus mengalami banyak sengsara (Kis. 14:22). ${ }^{48}$ Seperti yang diungkapkan Rasul Paulus, kita dipanggil bukan hanya untuk menjadi ahli waris, tetapi juga untuk menderita dengan-Nya. Inilah "tanda sebagai orang Kristen yang sejati”. 49

Bagi mereka yang belum percaya mungkin merasa ini hal yang mustahil, namun menurut Hodges, "hanya mereka yang begitu beriman sehingga bermegah dalam pengharapan pada kemuliaan Allah yang mampu untuk bermegah dalam kesengsaraan. Orang lain tidak dapat akan mengerti bahwa kesengsaraan yang kita alami sekarang "tidak dapat dibandingkan

\footnotetext{
${ }^{46}$ Th. van den End, Surat Roma (Jakarta: BPK Gunung Mulia, 1995), 222.

${ }^{47}$ Douglas Moo, The Wycliffe Exegetical Commentary Romans 1-8 (Chicago:

${ }^{48}$ Th. van den End, Surat Roma (Jakarta: BPK Gunung Mulia, 1995), 222.

${ }^{49}$ F. F. Bruce, Romans (Grand Rapids: InterVarsity, 1985), 114.
} Moody Press, 1991), 309. 
dengan kemuliaan yang akan dinyatakan kepada kita."50 Kemuliaan datang bukan sekedar membalas jasa kesengsaraan sekarang, itu adalah produk kesengsaraan. ${ }^{51}$

"Jika orang percaya ragu akan kebaikan dan janji Tuhan, atau kehilangan harapan dan bahkan pasrah, kesengsaraan-kesengsaraan ini akan membawa kekalahan rohani kepada orang percaya. Tetapi jika bermegah seperti yang diungkapkan Paulus, kesengsaraan-kesengsaraan akan menghasilkan kualitas rohani yang berharga seperti yang Paulus daftar pada ayat 3b-4." 52 Selanjutnya, menurut Th van de End, "kesengsaraan itu justru turut menandai persekutuann dengan Kristus, dan persekutuan itulah yang menjadi alasan kita bermegah., ${ }^{53}$

\section{Bermegah dalam Allah (5:11)}

Ini adalah ketiga kalinya Paulus menggunakan istilah 'bermegah' dalam pasal 5. "Bentuk kata kerja yang dipakai disini hendak mengungkapkan bahwa bermegah itu berlangsung terus-menerus dan berlangsung semata-mata dalam Allah. Bermegah adalah inti pokok dari perubahan yang nyata yang berlangsung dalam kehidupan orang yang menjadi percaya". ${ }^{54}$

Setelah memberikan penjelasan tentang apa yang telah dilakukan Allah melalui karya Yesus yang mati dan bangkit, untuk membenarkan, menyelamatkan dan memperdamaikan manusia (5:6-10). Paulus menunjukkan bahwa sekarang orang dapat bermegah di dalam Allah, karena keselamatan yang telah diberikan-Nya. Paulus menunjukkan pertentangan diayat sebelumnya, dengan keadaan manusia sebelumnya yang berada di bawah murka Allah dan kini mengalami keselamatan dari Allah. "Keselamatan" itu dikhususkan untuk orang percaya yang bermegah di dalam Allah. ${ }^{55}$ 2013), 106.

${ }^{50}$ Dave Hagelberg, Tafsiran Roma dari Bahasa Yunani (Bandung: Kalam Hidup,

${ }^{51}$ F. F. Bruce, Romans (Grand Rapids: InterVarsity, 1985), 115.

52 Douglas Moo, The Wycliffe Exegetical Commentary Romans 1-8 (Chicago: Moody Press, 1991), 309.

${ }^{53}$ Th. van den End, Surat Roma (Jakarta: BPK Gunung Mulia, 1995), 222.

${ }^{54}$ Ibid, 233. 2013), 114

${ }^{55}$ Dave Hagelberg, Tafsiran Roma dari Bahasa Yunani (Bandung: Kalam Hidup, 
Keselamatan itu hanya terjadi di dalam Yesus Kristus saja, Th van de End mengungkapkan, Oleh Yesus berarti, bahwa Dia (melalui Roh) mendorong kita untuk bermegah, untuk memuji-muji Tuhan. Bahkan dapat dikatakan juga bahwa puji-pujian kita layak diterima Allah karena perantaraan Dia. Dia yang oleh-Nya kita bermegah, Dia yang oleh-Nya kita diperdamaikan. Tambahan ini juga berarti bahwa Dia menjadi dasar kita bermegah. ${ }^{56}$ Pengorbanan Yesus telah menjadi dasar pijakan orang percaya untuk bermegah. Sebab tanpa-Nya, pemulihan hubungan manusia dengan Allah tak dapat terealisasikan.

\section{Teladan Paulus: Bermegah dalam Allah (Roma 15:17)}

Paulus adalah Rasul yang terkenal dalam dunia Perjanjian Baru. Di dalam kitab Roma, Paulus menuliskan bahwa Allah telah menjadikannya rasul bagi banyak bangsa-bangsa bukan Yahudi (Roma 15:16). Paulus memang memiliki jabatan yang unik sehingga ia seakan-akan menyajikan bangsa-bangsa kepada Allah, dengan menyebarkan Injil di tengah-tengah bangsa-bangsa itu. Maka ia mempunyai alasan untuk bermegah karena pelaksanaan tugas ilahi. ${ }^{57}$

Namun disini, Paulus menyatakan bahwa kemegahan itu berada di dalam Yesus Kristus. Ia bermegah dalam Kristus dan Roh Kudus yang telah menyelesaikan dalam dunia dan menyatakan melalui pelayanannya. ${ }^{58}$ Paulus menyadari sepenuhnya bahwa keberhasilannya dalam pelayanan kepada bangsa-bangsa lainnya bukanlah karena kekuatannya sendiri, tetapi karena Allah. Allahlah pemberi tugas, Paulus hanya sebagai pelayan-Nya. ${ }^{59}$ Alasan kemegahan Paulus hanya terletak di dalam Allah dan untuk Allah (Rm. 15:17). Memang ia bangga sekali bahwa pelayanan seperti itu dipercayakan kepadanya, tetapi ia menyebutkan batas kebanggaan itu dalam ayat berikutnya. ${ }^{60}$

${ }^{56}$ Th. van den End, Surat Roma (Jakarta: BPK Gunung Mulia, 1995), 234.

${ }^{57}$ Ibid, 673.

${ }^{58}$ Matthew Black, The New Century Bible Commentary (Grand Rapids: Eerdmans Publishing Company, 1989), 203.

${ }_{59}$ Th. van den End, Surat Roma (Jakarta: BPK Gunung Mulia, 1995), 673. 2013), 326.

${ }^{60}$ Dave Hagelberg, Tafsiran Roma dari Bahasa Yunani (Bandung: Kalam Hidup, 


\section{Implikasi Praktis bagi Gereja Masa Kini}

Dalam konteks gereja dapat saja terjadi karena jabatan atau kedudukan di gereja menjadikan diri seseorang menjadi bangga, dan lebih terhormat karena kedudukan tersebut. Sejarawan Ambrosiaster, 1580 mengungkapkan bahwa dalam gereja Roma yang disebut pelayan gereja Roma, dianggap lebih terhormat daripada pelayan gereja lainnya. Terjadi rivalitas di dalam gereja Roma yang mau menyamakan kedudukan kaum Lewi dengan imam, diaken, presbiter. ${ }^{61}$ Dalam tulisan artikel Paul And Plutarch On Boasting, pandangan Paulus, dan Plutarch mengenai bermegah adalah dua hal yang bertolak belakang. Pandangan Paulus bermegah dalam kesengsaraan, berbeda dengan pendapat umum kuno dan modern, yaitu pahala, dan keberhasilan adalah sumber kemuliaan. Plutarch patuh untuk pandangan ini; dia hanya bisa bertanya pahala yang lebih baik; kebaikan, kebajikan, keadilan, grasi atau prestasi politik dan penghargaan. ${ }^{62} \mathrm{Hal}$ itu tentunya terjadi pula dengan konteks gereja masa kini. Oleh karena itu, gereja perlu kembali kepada pengajaran bermegah di dalam Allah, bukan kepada taurat atau aturan manusia, dan organisasi.

Gereja dalam hal ini orang percaya yang melayani Tuhan memiliki kemegahan di dalam Allah, Hanya itulah kemegahan yang sejati. Bermegah dalam pengharapan oleh iman kepada Yesus Kristus, bermegah dalam penderitaan karena Kristus, bermegah hanya di dalam Allah saja yaitu sumber kemegahan itu sendiri. Bermegah dalam konteks gereja sebagai perspektif yang baru yang juga sesuai dengan pembaca surat Roma pada masa Paulus menunjukkan tentang imlplikasinya dalam doktrin Pembenaran dan Keselamatan. ${ }^{63}$

\section{Kesimpulan}

Kata bermegah dalam kitab Roma awalnya dipakai dengan bentuk kecaman-kecaman kepada orang Yahudi yang bermegah di dalam taurat. Hal ini dilakukan untuk menanamkan isi yang berlawanan dengan gagasan

${ }^{61}$ David G. Hunter, "Rivalry between Presbyters and Deacons in the Roman Church: Three Notes on Ambrosiaster, Jerome, and The Boasting of the Roman Deacons," Vigiliae Christianae 71, no. 5 (November 10, 2017): 495-510.

${ }^{62}$ Michael Wojciechowski, "Paul and Plutarch On Boasting," Journal of GrecoRoman Christianity and Judaism 3 (2006): 99-109.

${ }^{63}$ Gathercole, Where Is Boasting?, 1. 
kemegahan. Dalam konsep bermegah, Paulus hendak mengaitkannya dengan dasar menaruh tempat kepercayaan yang benar. Di sini, Paulus menolak semua dasar bermegah di luar dari Injil. Hanya Injil yang dapat membuktikan bahwa semua kemegahan yang lainnya tidak dapat diandalkan.

Di dalam Injil, manusia dapat bermegah, karena karya pendamaian Yesus di kayu salib bagi manusia sehingga manusia dapat kembali memiliki hubungan dengan Allah. Kemegahan itu berlangsung terus-menerus di dalam Allah. Ini merupakan inti pokok yang ditunjukkan dari seorang percaya yang telah mengalami perubahan. Kehidupan orang percaya akan bermegah bukan hanya di dalam hal-hal yang baik saja, namun hingga ke tahap menderita, orang percaya akan tetap bermegah. Kesengsaraan di dalam kehidupan orang percaya bukan lagi menjadi tanda murka Allah melainkan bagaimana mereka telah memperolah keselamtan dari murka itu. Orang percaya yang bermegah di dalam Allah adalah orang percaya yang melakukan kebenaran Allah dalam kehidupannya. Toews berpendapat Kebenaran Allah adalah kebenaran yang dimiliki Allah; itu menggambarkan karakter Allah sebagai Allah yang benar yang ada dan bertindak selayaknya dalam semua hubungan. Dengan demikian Allah menghendaki manusia memiliki hubungan yang benar dengan Allah, dan sesama. Kebenaran Allah itulah jalan keselamatan.

\section{Daftar Pustaka}

Barclay, William. Pemahaman Alkitab Setiap Hari Roma. Jakarta: Gunung Mulia, 1968.

Black, Matthew. The New Century Bible Commentary. Grand Rapids: Eerdmans

Publishing Company, 1989.

Bruce, F. F. Romans. Grand Rapids: InterVarsity Press, 1985.

End, Th van den. Surat Roma. Jakarta: BPK Gunung Mulia, 1995.

Frederik, Hanny. "Konsep Persatuan Dengan Kematian Dan Kebangkitan

Kristus Berdasarkan Roma 6:1-14." Jurnal Jaffray Vol.13, no. 2 (September 29, 2015): 215-248.

Gathercole, Simon J. Where Is Boasting? Early Jewish Soteriology and Paul's Response in Romans 1-5 / Simon J. Gathercole. Grand Rapids, Mich: William B. Eerdmans Pub. Co, 2002. 
Konsep Bermegah (Boasting) dalam....(Shintia Maria, Hengki Wijaya)

Hagelberg, Dave. Tafsiran Roma dari Bahasa Yunani. Bandung: Kalam Hidup, 2013.

Harlow, R. E. Alive and Free. Canada: Everyday Publication, 1977.

Hunter, David G. "Rivalry between Presbyters and Deacons in the Roman Church: Three Notes on Ambrosiaster, Jerome, and The Boasting of the Roman Deacons." Vigiliae Christianae Vol.71, no. 5 (November 10, 2017): 495-510.

Jaffray, R. A. Tafsiran Surat Rasul Paulus kepada Orang Rum. Bandung: Kalam Hidup, 1968.

Keener, Craig S. Romans. United States America: Cascade Books, 2009.

Moo, Douglas. The Wycliffe Exegetical Commentary Romans 1-8. Chicago:

Moody Press, 1991.

Ridderbos, Herman. Paulus Pemikiran Utama Theologinya. Surabaya: Momentum, 2010.

Rouw, Julian Frank. "Kajian Konseptual Tentang Pemilihan Allah Dalam Roma 9." Evangelikal: Jurnal Teologi Injili dan Pembinaan Warga Jemaat 1, no. 2 (2017): 170-183.

Talbert, Charles H. Romans. Smyth \& Helwys Bible commentary. Macon, Ga: Smyth \& Helwys, 2002.

Toews, John E. Romans. Believers church Bible commentary. Scottdale, Pa: Herald Press, 2004.

Wijaya, Hengki. Metodologi Penelitian Pendidikan Teologi. Makassar: Sekolah Tinggi Theologia Jaffray, 2016.

Wojciechowski, Michael. "Paul and Plutarch On Boasting." Journal of Greco-Roman Christianity and Judaism 3 (2006): 99-109.

Zaluchu, Sonny. "Penderitaan Kristus Sebagai Wujud Solidaritas Allah Kepada Manusia." Dunamis: Jurnal Teologi dan Pendidikan Kristiani 2, no. 1 (November 4, 2017): 61-74. 